\title{
BAP1 Mutation Analysis
}

National Cancer Institute

\section{Source}

National Cancer Institute. BAP1 Mutation Analysis. NCI Thesaurus. Code C157167.

A procedure used to detect and identify mutations in the BAP1 gene. 